\title{
Connectivity of Tropical Marine Ecosystems: An Overview of Interdisciplinary Research to Understand Biodiversity and Trophic Relationships in the Virgin Islands and Puerto Rico
}

\section{Tropical Marine Reserves and Protected Areas}

The Virgin Islands and Puerto Rico contain marine reserves and protected areas that encompass a variety of tropical ecosystems, including coral reefs, mangroves, and seagrass beds (fig. 1). Reserves and protected areas are established for a variety of reasons, such as preserving nursery habitats and biodiversity, or reducing anthropogenic effects associated with pollution and land use. Questions remain regarding the effectiveness of these designated areas in preserving and protecting spatially connected habitats and associated fishes and invertebrates. Scientists from the U.S. Geological Survey (USGS), University of Florida, and Arkansas State University are collaborating on interdisciplinary research in the Virgin Islands and Puerto Rico to examine the biodiversity and trophic dynamics of fishes and invertebrates residing in connected mangroves, seagrasses, and coral reefs to discern the effectiveness of current marine reserves and protected areas for conserving reef resources.

\section{Trophic Relationships}

Energy transfer within and among tropical marine ecosystems involves communities associated with reefs, mangroves, and seagrass beds. Little is known about the influence of fish habitat utilization, prey preferences, and movement patterns, on the flow of energy occurring between trophic levels (that is, from a prey to its predator).
Collaborative research efforts are using telemetry and stable isotope analyses (SIA) to track fish movement patterns (for example, schoolmaster snapper, Lutjanus apodus) in and out of connected habitats, marine reserves and protected areas, and identifying invertebrates found within fish foraging habitats (fig. 2). Additionally, researchers are characterizing trophic relationships between fishes and their prey by examining fish stomach contents and conducting SIA of fishes and invertebrates. These efforts could identify critical habitats used by fishes (both within and outside the reserves and protected areas) and quantify these habitats as foraging sites. Findings from this research may assist government officials in designating appropriate areas for protection.

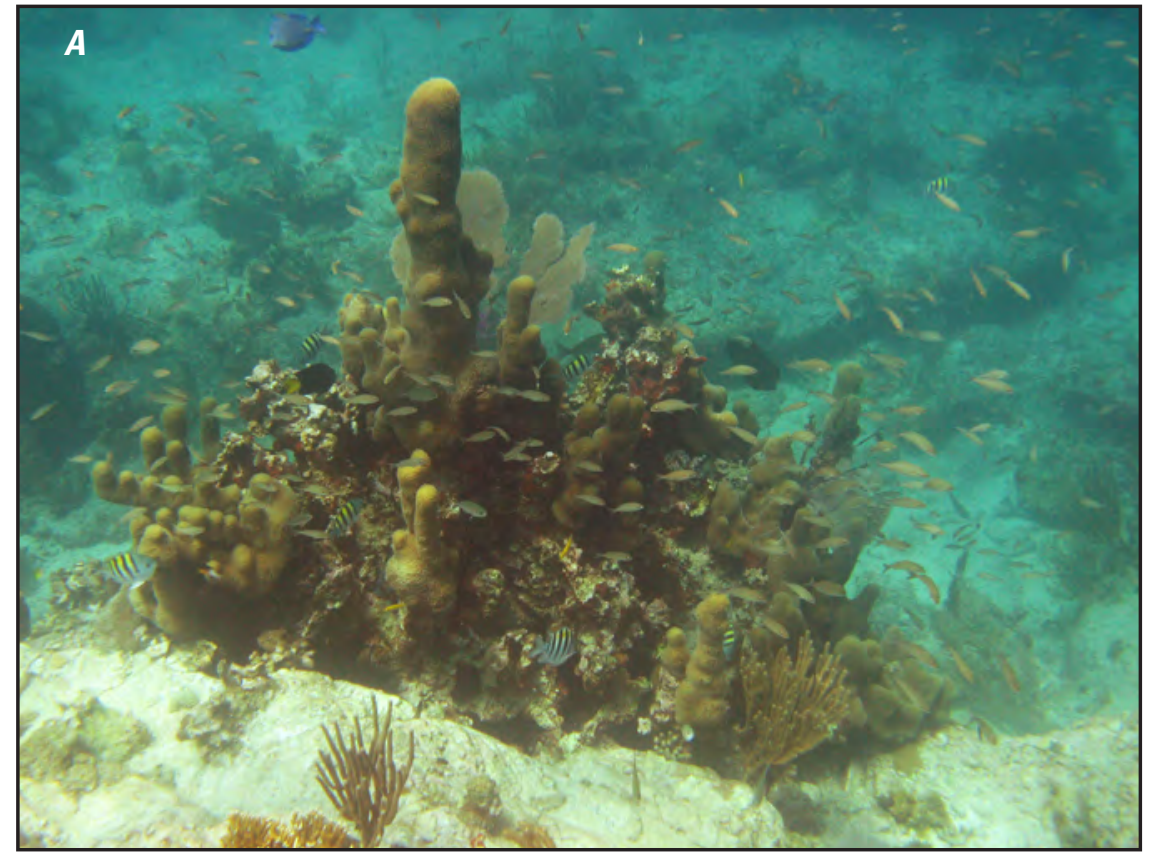

Figure 1. Examples of $A$, coral reefs, $B$, mangroves, and $C$, seagrass beds sampled during this interdisciplinary research of tropical marine ecosystems. Photographs by Amanda Demopoulos, USGS.

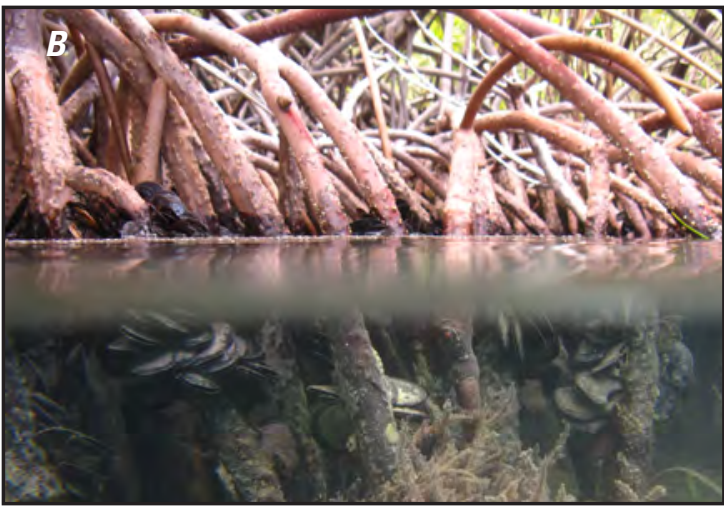

$c$

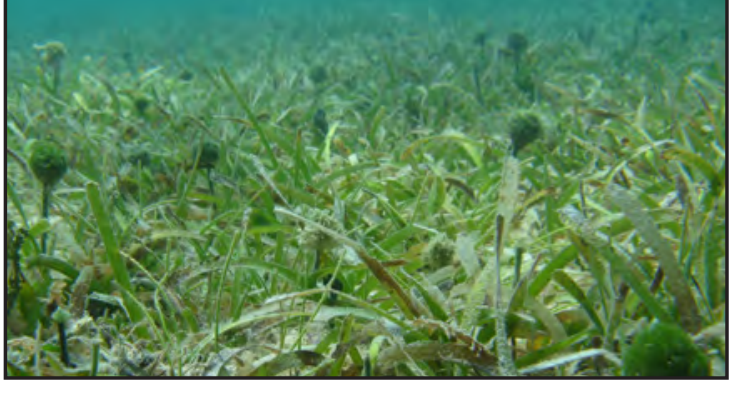




\section{The Role of Parasitism}

Parasitism is an important ecological interaction that affects community and trophic structure of coral reefs and connected habitats. However, the influence of parasites on food webs has been largely ignored (Lafferty and others, 2008). Parasites attached to the outside of reef fishes - known as ectoparasites - can be transferred between habitats by their hosts (Grutter, 1998). Ectoparasites can be consumed by cleaner organisms, such as shrimp, or become dislodged and return to the benthos; both circumstances are potential mechanisms for transferring energy among habitats (fig. 3).

Through the use of SIA and parasite feeding experiments, this research will advance understanding of host-parasite and parasite consumer trophic relationships and their influence on coral reef food-web dynamics. Additionally, this research is addressing how human activities, such as pollution and land use that can cause increased sedimentation and eutrophication, may affect reef habitats and associated parasite-host interactions.

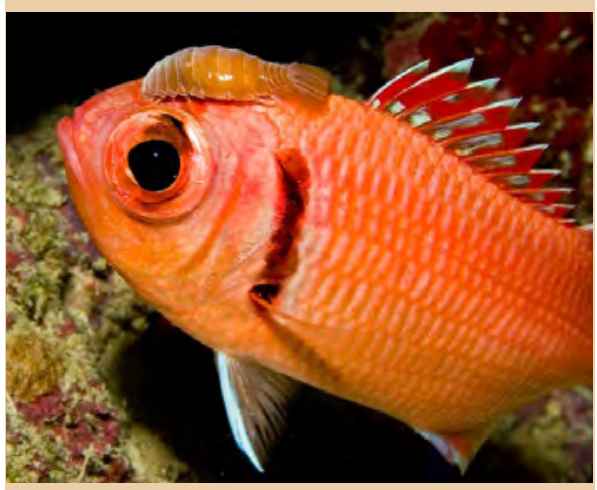

Figure 3. An ectoparasite (Anilocra sp.) on a blackbar soldierfish (Myripristis jacobus). Photograph by Philip Hodgens.

\section{Biodiversity and Species Identification}

Conservation efforts in the Virgin Islands and Puerto Rico are dependent on good documentation of species present within the mangroves, seagrass beds, and coral reefs. Benthic invertebrates are an integral part of these habitats, but the scarcity of species
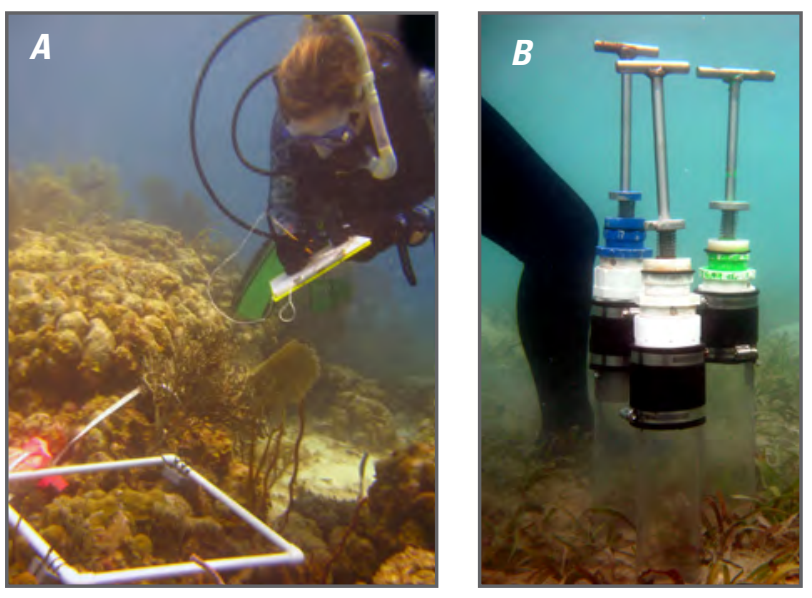

Figure 2. A, A USGS employee records marine organisms present in a $0.5 \mathrm{~m}^{2}$ quadrat in a coral reef. $B$, Push cores sampled benthic invertebrates in seagrass beds. Both types of sampling occurred in all habitat types. Photographs by Amanda Demopoulos, USGS.

descriptions for the majority of invertebrate taxa and incomplete taxonomic keys make it difficult to assess invertebrate diversity and species composition. DNA barcoding is a molecular technique that can assist with species discoveries, identify unknown or poorly defined taxonomic groups and cryptic species, and improve the quality and quantity of data available for conservation efforts (Neigel and others, 2007). USGS is developing markers for a DNA barcoding technique to complement traditional morphology-based identification with the goal of improving identification and understanding of the diversity within habitats. DNA barcoding will also help to identify marine organisms in fish stomachs, thus providing data on prey consumed by reef fishes. This information, coupled with the invertebrate surveys described above, will enhance scientific understanding of the invertebrate resources available in fish foraging areas.

\section{Connectivity of Tropical Ecosystems}

Many of the organisms examined for these studies are important prey to higher trophic levels. For example, French grunt (Haemulon flavolineatum) habitat requirements and movements likely influence other ecologically and economically important species, such as red hind (Epinephelus guttatus). The interdisciplinary research described here will enhance our understanding of the complex biological and ecological interactions among resident and transient reef organisms. This knowledge is a critical component for evaluating the effectiveness of marine reserves and protected areas and determining whether designated areas may need to incorporate additional habitat types.

\section{References Cited}

Grutter, A., 1998, Habitat-related differences in the abundance of parasites from a coral reef fish: An indication of the movement patterns of Hemigymnus melapterus (Bloch, 1791) (Labridae), Journal of Fish Biology, v. 53, p. 49-57.

Lafferty, K.D., Allesina, S., Armi, M., Briggs, C.J., De Leo, G., Dobson, A.P., Dunne, J.A., Johnson, P.T.J., Kuris, A.M., Marcogliese, D.J., Martinez, N.D., Memmott, J., Marquet, P.A., McLaughlin, J.P., Mordecai, E.A., Pascual, M., Poulin, R., and Thieltges, D.W., 2008, Parasites in food webs: The ultimate missing links: Ecology Letters, v. 11, p. 533-546.

Neigel, J., Domingo, A., and Stake, J., 2007, DNA barcoding as a tool for coral reef conservation: Coral Reefs, v. 26, p. 487-499.

By Jennifer McClain-Counts and Amanda Demopoulos

\section{For additional information, contact:}

Amanda Demopoulos

USGS Southeast Ecological Science Center 7920 NW 71st Street

Gainesville, Florida 32653

352-264-3490

ademopoulos@usgs.gov

http://pubs.usgs.gov/fs/2012/3016

Publishing support provided by the USGS Science Publishing Network, Raleigh Publishing Service Center 